\title{
Features of video conferencing as forms of mutual legal assistance in criminal matters
}

\section{Dildora UMARKHANOVA ${ }^{1}$}

Tashkent State University of Law

\begin{tabular}{l} 
ARTICLE INFO \\
\hline Article history: \\
Received September 2020 \\
Received in revised form \\
15 September 2020 \\
Accepted 15 October 2020 \\
Available online \\
30 October 2020
\end{tabular}

\section{Keywords:}

international cooperation videoconferencing mutual legal assistance international treaty technology innovation

\section{ABSTRACT}

The article analyzes the features of videoconferencing as a form of mutual legal assistance in criminal cases and the need for its use. The author explores the international and national legal framework for using video conferencing tools as innovative technologies. As a result of the study, gaps in the legislation on the use of videoconferences in matters of international cooperation in criminal matters were identified. In addition, the experience, advantages and disadvantages of foreign countries in using this form of mutual legal assistance are considered, and the relevant practice is studied in detail. Current article is enriched with real life examples. As a result, the features of the use of videoconferencing in mutual legal assistance in criminal cases, as well as the consequences and conveniences of using these tools in pandemic situation were identified, and proposals were developed to amend the relevant legislation.

2181-1415/C) 2020 in Science LLC.

This is an open access article under the Attribution 4.0 International (CC BY 4.0) license (https://creativecommons.org/licenses/by/4.0/deed.ru)

\section{Жиноят ишлари бўйича ўзаро хуқуқий ёрдам шакли сифатида видеоконференцалоқа хусусиятлари}

\begin{tabular}{l}
\hline Калит сўзлар: \\
халқаро хамкорлик \\
видеоконференцалоқа \\
узаро хуқуқий ёрдам \\
халқаро шартнома \\
технология \\
инновация
\end{tabular}

Калит сўзлар:

видеоконференцалоқа

ўзаро хуқуқий ёрдам

технология АННОТАЦИЯ

Ушбу мақолада жиноят ишларида ўзаро хуқуқий ёрдам шакли сифатида видеоконференцалоқа хусусиятлари ва уни қўллаш зарурлиги тахлил қилинди. Муаллиф томонидан инновацион технологиялар каби видеоконференцалоқа воситаларидан фойдаланишнинг халқаро ва миллий хуқуқий асослари ўрганилди. Ўрганиш натижасида, жиноят ишлари бўйича халқаро хамкорлик масалалаларида видеоконференцалоқадан фойдаланиш

\footnotetext{
${ }^{1}$ Doctor of sciences (DSc) of law, associate professor, Tashkent State University of Law, Tashkent, Uzbekistan Email: ad.umarxanova@tsul.uz
} 
бўйича қонунчиликдаги бўшлиқлар аниқланди. Бундан ташқари, хорижий мамлакатлар мазкур ўзаро хуқуқий ёрдам шаклидан фойдаланиш тажрибаси, ютуқ ва камчиликлари хам кўриб чиқилди ва тегишли амалиёт чуқур ўрганилди. Хаётий мисоллар билан бойитилди. Натижада, жиноят ишлари бўйича ўзаро хуқуқий ёрдам масалаларида видеоконференцалоқа шаклидан фойдаланишнинг ўзига хос томонлари хамда пандемия шароитида мазкур воситалардан фойдаланишнинг оқибатлари, қулайликлари очиб берилди ва тегишли қонунчиликка ўзгартириш киритиш бўйича таклифлар ишлаб чиқилди..

\section{Особенности видеоконференцсвязи как формы взаимной правовой помощи по уголовным делам}

\begin{tabular}{l}
\hline Ключевые слова: \\
международное \\
сотрудничество \\
видеоконференции \\
взаимная правовая \\
помощь \\
международный договор \\
технологии \\
инновации
\end{tabular}

\section{АННОТАЦИЯ}

\begin{tabular}{l} 
В статье \\
\hline
\end{tabular}

\section{INTRODUCTION}

In the era of globalization, the growth of organized crime requires the use of new methods and means of international cooperation in criminal matters, such as threats to the security of individual states or international security, creating obstacles to sustainable development, and the appearance of cruel types of crimes committed. As a result of a quick understanding of the methods of committing crimes, the use of the most advanced techniques in their implementation, criminals commit grave crimes with transnational characters, and they are able to earn huge profits. At the same time, using them in the process of collecting evidence and evidence in a criminal case to bring to criminal responsibility today causes much more problems. This requires not only improving methods and means of combating 
transnational crime, but also creating new mechanisms for the provision of mutual legal assistance in criminal matters.

Mutual legal assistance in criminal matters is a request for assistance in obtaining evidence of crime, which mainly belongs to the competent authorities of states. Thus, it is possible to characterize the issues of mutual legal assistance in criminal matters, applying for assistance in collecting evidence for use by the state in criminal matters, as well as the process of satisfying or dissatisfying such an appeal, as well as creating conditions for effective and immediate, comprehensive assistance between them.

\section{LEGAL REGULATION OF MUTUAL LEGAL ASSISTANCE IN CRIMINAL MATTERS}

Mutual legal assistance in criminal matters can be carried out at all stages of the criminal process, which includes: interrogation as a witness, provision of documents of significant importance, acts, written documents, video, audio recording materials and other similar documents.

It is worth noting that the scope of this area of international cooperation in criminal matters is constantly expanding. In this regard, a number of recommendations and model agreements aimed at improving the international legal framework for UN cooperation in the field of criminal justice which indicate the main forms of mutual legal assistance in criminal matters that have developed in practice [1].

One of the first examples of the legal framework governing the provision of mutual legal assistance in criminal matters is the European Convention on Mutual Legal Assistance in Criminal Matters, which was developed by the Council of Europe in 1959 and is currently in use. The structure of this convention has been expressed as an important instrument of cooperation for the collection of evidence between states. Mutual legal assistance is also currently based mainly on bilateral and multilateral agreements. Over the years, some international treaties (for example, Treaties to combat transnational crime and corruption [2]) have served as models for combating or preventing certain crimes.

With regard to bilateral agreements, it should be remembered that over the years of independence, Uzbekistan has signed agreements on legal assistance in criminal matters with a number of foreign countries. In particular, agreements with Turkey in 1994, Latvia in 1996, Lithuania, Georgia, Kyrgyzstan, Turkmenistan, Kazakhstan in 1997, Azerbaijan, the People's Republic of China, Ukraine in 1998, India in 2000, Pakistan in 2007, and Czech Republic in 2002, Korea and Bulgarian 2003, United Arab Emirates in 2014.

At the same time, it should be noted that in the Criminal Procedure Law of the Republic of Uzbekistan and in the Criminal Procedure Law of other CIS countries the forms of legal assistance are not clearly indicated in the form of distribution by type. At the same time, forms of legal assistance are described in paragraph 5 of the Resolution of the Plenum of the Supreme Court of the Republic of Uzbekistan dated May 25, 2012 «On some issues of international cooperation in the field of legal proceedings in civil and criminal cases». According to him, in accordance with international treaties of the Republic of Uzbekistan, legal assistance in the field of criminal proceedings, including in the following forms:

- leaving, sending, presenting materials and originals and certified copies of banking, financial, legal and other documents, transferring;

- search, seizure of objects and documents, identification and correspondence of property, determination of the income of an individual, direction and issuance of material evidence; 
- viewing, watching;

- examination;

- interrogation of plaintiffs, defendants, third parties (their representatives), victims, defendants (defendants), witnesses, experts;

- the search for missing persons, as well as the search and detention of persons accused of committing a crime;

- criminal proceedings;

- submission of court documents, including copies of court decisions or court orders, references to a guilty verdict (if necessary, with the addition of the text of relevant legislative norms) [3];

In the field of criminal proceedings, legal assistance may also be provided in a different form that does not contradict the law.

In terms of the scope of the issue of mutual legal assistance in criminal matters, it is the most widely used institution in practice in other areas of cooperation, since this area of law consists of two branches of law, namely International Law and Criminal Procedure Law, which are used by the competent authorities to implement international cooperation.

We know that the competent authorities of the state, requesting legal assistance in criminal matters, carry out certain procedural actions in accordance with their national procedural legislation.

Due to the fact that the provision of legal assistance in criminal matters differs from other areas of cooperation in the field of criminal cases. It should be noted that the state requesting legal assistance also has partial powers to conduct criminal proceedings. The powers of the competent authorities of the requesting state in a criminal case are also partially transferred to the competent authorities of the requested state along with statements on the collection of evidence, the implementation of certain other procedural actions, and the conduct of operational-search measures. That is, the competent authorities of the state are allowed to carry out by the competent authorities of this state in accordance with the national legislation of the state, in which their powers are requested in connection with certain procedural actions in a criminal case during the proceedings. It is recognized here if the requested state complies with the requirements of the national Criminal Procedure Law in relation to the receipt and execution of applications, statements reflecting material evidence, other procedural actions collected in a criminal case by its competent authorities in accordance with the state criminal procedure law [4].

As noted above, international cooperation in the field of mutual legal assistance in criminal matters is carried out on the basis of special legal acts regulated by international and domestic legislation. The procedural legal basis of international legal cooperation in criminal matters in the Republic of Uzbekistan is provided for by the norms of 64 chapters of the Code of Criminal Procedure, according to which such cooperation is carried out if a suspect or accused in a criminal case initiated in the territory of one state is hiding in the territory of another state, witnesses criminal proceedings instituted in the territory of another state are on the wanted list.

In this regard, the competent authorities of the Republic of Uzbekistan and foreign states turn to each other for assistance in the search for a suspect or accused, his arrest or detention, bringing him to criminal responsibility, referring him to an investigation and fair trial in this criminal case, and also during investigative actions that do not have the ability to be proved. 
According to the general rule established in the Code of Criminal Procedure, if it is necessary to conduct interrogation, examination, arrest, search, forensic examination or other investigative actions in the territory of a foreign state, the authorized body of the Republic of Uzbekistan sends a corresponding application to the authorized body of a foreign state to provide legal assistance in a criminal case. The procedure, content and form for submitting such an application are clearly spelled out in article 593 of the Code of Criminal Procedure, as well as in international treaties on legal assistance in criminal matters in which the Republic of Uzbekistan is participated.

An analysis of bilateral agreements on the provision of legal assistance in criminal matters of the Republic of Uzbekistan shows that some of them have rules on the need to consider an application in a special form and on established conditions. Such special conditions must be indicated in the application and not contradict the legislation of the state to which the application was sent. Such standards, in our opinion, should be considered as the legal basis for the use of video conferencing, which is one of its forms in the execution of applications for the provision of legal assistance.

\section{DISCUSSION}

In recent years, there has been a tendency to introduce innovative technologies in various spheres of state and public activities. Research and analysis of judicial practice in the system of means and methods of collecting evidence in criminal cases effectively use new technical means. Despite the difficulties in applying the law, at present there is experience in using audio, video recordings and other technical means that fully, accurately and objectively reflect the process of collecting evidence in a criminal case.

A vivid example of this is the interrogation of former President of Ukraine Viktor Yanukovych in the Rostov Regional Court of Russia as a witness to the events of 2014 in the city center of Kiev «Independence Square» [5].

Thus, this situation indicates the relevance of the introduction of new technologies, such as video conferencing, in the event of a preliminary investigation and the procedural activities of the judiciary. Currently, the criminal procedural legislation of Uzbekistan does not have a legal basis for the use of this innovative technology, significantly reduces the scope and possibility of using video conferencing.

At the same time, the need to expand the practical application of this form of mutual legal assistance in criminal matters is justified by the prevention of an increase in the volume of work of the authorized bodies, the expansion of the use of modern technologies.

It should be noted that for the filing of applications for mutual legal assistance in criminal cases, it will take from 6 months to two years, and in some cases even more [6].

As a result of the legal regulation of the use of modern technologies, such as video conferencing (if the necessary technical and specific methodological recommendations are available), the implementation of requests for mutual legal assistance in criminal cases will lead to a reduction in the time for their execution, an improvement in the quality of their consideration, and a significant reduction in the cost of financial resources, and will also lead to an increase in the timing of criminal cases [7].

There are not only technical, but also legal problems of using videoconferencing in the field of mutual legal assistance in criminal matters. Despite the fact that the current legislation contains rules that make it possible to use it, they do not specify the limit of information that can be obtained only through video conferencing, which is associated with the stage of the 
trial and the press, the purpose and mechanism of application of these information and communication technologies, as well as in the case of video conferencing. At the same time, the use of innovative technologies in the criminal process, in particular in the provision of mutual legal assistance in criminal matters, has not been scientifically studied.

This indicates the need for in-depth scientific research on issues such as the legal basis for the application of this technology in criminal proceedings, the limits and procedure for its application, as well as the legal force of information obtained through video conferencing, as well as the need for appropriate executive clarification.

A study of the experience of foreign countries shows that the regulatory framework for the use of video conferencing in a number of foreign countries has been created, as well as the experience gained from its use in criminal proceedings (for example, Australia, Great Britain, Germany, India, Italy, Canada, New Zealand, USA, Ukraine, Finland, Estonia). It is obvious that the use of cross-border experience in this area will lead to the development of the field of video conferencing, the application of the capabilities of video conferencing in practice [8].

Although the Republic of Uzbekistan also pays special attention to the legal regulation of the use of innovative technologies, such as video conferencing, in recent years it should be noted that this experience is not subject to research or judicial practice. In order to partially eliminate such gaps in practice, the Decree of the President of the Republic of Uzbekistan «On measures to radically improve the activities of the internal affairs bodies in the field of criminal investigation» determined that by January 1, 2018, special cabinets for shorthand, video surveillance would be equipped in the internal affairs bodies, and also for conducting operational-search measures [9].

Since the prospect of introducing video conferencing into the legal sphere is obvious, it is advisable to use models in which the use of video conferencing is manifested on the positive side abroad. Without going into technical details, we can say that its essence lies in the fact that to use such a connection, a separate channel must be developed or one of the existing channels should be selected, which not only ensures confidentiality and the corresponding quality of the information transmitted through this channel, but also establishes relevant requirements for the technical means by which such a connection is made.

It should be noted that, currently videoconferencing is not widely used in the process of collecting evidence in criminal cases. In the United States, videoconferencing uses a judicial procedure (precedent) to receive instructions from an accused or witness, while national law does not deny this. Under bilateral criminal law mutual assistance agreements concluded by the United States, mutual cooperation can take place through any process that does not conflict with US law. Obtaining instructions using video conferencing technology as part of the provision of mutual legal assistance does not lead to a violation of legal norms on their own [10].

In addition, it is clearly indicated that the receiving party of the instructions in the federal rules governing the testimony process has the right to choose whether these instructions are recorded by voice, visual or verbatim means, and the court may decide to record the instructions using electronic means of telephone or other remote communication , including video conferencing. Therefore, most law enforcement agencies have specially equipped facilities designed for video conferencing, which is used in the investigation of crimes. Thus, the US Department of Justice's Prosecution Department, the Federal Bureau of Investigation, and other investigative agencies have video communications designed to be used by the same authorities [10]. 
Such equipped facilities are available in every federal district where the federal criminal prosecution service is located throughout the country, as well as in most local law enforcement agencies. In the interests of law enforcement, commercial organizations are allowed to use video conferencing, but US law enforcement agencies have concluded that it is more advisable to conduct video conferencing by acquiring the necessary techniques and concluding agreements with telecommunication service providers [7].

In the United States, there are no federal rules or other laws governing the implementation of investigative actions using video conferencing. Typically, such issues are decided by the presiding judge, based on practice (based on precedents). However, the federal rules governing the receipt of instructions from a witness in the territory of another state stipulate that «in order to conduct a fair trial, in case of exception, the instructions of the future witness must be adopted and observed [8].

As an exception, assessment factors are included in the absence of a witness to testify during the trial. When the Bunda speaks of the "non-participation" of judges, this is interpreted as a lack of desire to participate in the hearing to testify, unless the obligation to arrive is supported by a court order in respect of the witness. Under this rule, non-US citizens located in a foreign country cannot participate in the judicial complex [10]. In accordance with the norms established by law, the testimony of a witness can be recorded before the trial and presented as evidence during the trial. U.S. federal law permits the use of video conferencing to receive instructions before and during a court hearing.

The issue of the use of video conferencing in criminal proceedings is also provided for by Canadian law. The Canadian Penal Code provides that a defendant is simultaneously involved in a trial through visual communication in any legal process (unless he has obtained a witness testimony) through cable television or other means (Section 650) [11]. To carry out such participation, the following prerequisites must be met:

1. court decision or consent;

2. consent of the prosecutor and the defendant;

3. creation of conditions for the prosecution to be presumptuous in the confidential form of the defendant during the trial.

According to article 606 of the Criminal Code of Canada, the fact that the accused may complain about the video is also reinforced. Despite the fact that obtaining witness orders in a remote form is indicated only if the equipment is subject to it (Article 700 of the Criminal Code of Canada), cases in which video recording is allowed by the court in accordance with part 1 of Article 714 of the Criminal Code of Canada are clearly defined. This is the location and personal conditions of the witness; personal participation of the witness in the process; The nature of the expected instructions. According to the court, if it does not contradict the basic printouts of justice and there is no notice to the parties, the certificate can also be obtained outside of Canada through a video card (article 714 of the Criminal Code of Canada).

\section{CONCLUSION}

The use of the videoconferencing procedure described above in judicial and investigative processes can give a positive result. Because, having many years of experience, national and international foundations have been settled, and the positive and relevant aspects of our legal system, which today is yielding results, is now an opportunity for a developing and emerging state. 
In order to accurately determine the use of videoconferencing as considered a new form of mutual legal assistance in criminal matters, which is not regulated by national legislation, as well as the use of audio and video recordings as evidence in criminal cases, it is advisable to introduce a separate article in the Code of Criminal Procedure of the Republic of Uzbekistan. The use of video conferencing during the conduct of these investigative actions should be explained by circumstances, that is, in connection with a difficult Evan member of the investigative action is not able to appear before the investigating authority or by the investigator, the need to ensure the safety of persons involved in criminal proceedings, the presence of participants of investigatory actions the possibility to come to the investigative body or the investigator. In addition, the witness, victim, expert, expert, suspect, accused, civil plaintiff, civil defendant and their representatives should be provided for during the interrogation, as well as during the interrogation, presentation, presentation for confession, testimony, investigative experiment and examination of evidence at the scene and should be used.

The proposed article considers cases where the implementation of investigative actions is not allowed using video conferencing. This should be determined by the fact that the person designated for conducting investigative actions using video conferencing is not able to hear and see, and that video conferencing should not be carried out if appropriate means or communication channels are not available at one of the video conferencing venues.

In turn, the need to find a scientific and practical solution to the above issues, as well as the previously undeveloped legal mechanism for the provision of mutual legal assistance in criminal matters, determines its theoretical and practical significance by applying these discussed forms to national legislation. The problem of using videoconferencing in criminal proceedings is considered through the problem of international cooperation in criminal matters.

\section{References}

1. http://www.un.org/ru/documents/decl conv/conventions/mutual assistance.s $\underline{\mathrm{html}}$

2. United Nations Convention against Transnational Organized Crime Adopted by General Assembly resolution 55/25 of 15 November 2000. International law and the fight against crime: Collection of documents / Compilers: A.V. Zmeevsky, Yu.M. Kolosov, N.V. Prokofiev. - M.: International Relations, 2004. - S. 433-478.

3. Resolution of the Plenum of the Supreme Court of the Republic of Uzbekistan "On some issues of international cooperation in the field of legal proceedings in civil and criminal cases" 05/25/2012. №6. www.lex.uz

4. David Mcclean. International co-operation in civil and criminal matters. Third edition. Oxford University Press. 2012. - P.185-189.

5. http://radiovesti.ru/news/572403/

6. Bastrykin A. We have many things in common // Rossiyskaya Gazeta (Special Issue) European Union. June 9, 2011 No. 5499

7. Shari Seidman Diamond, Locke E. Bowman, Manyee Wong, Matthew M. Patton. Efficiency and Cost: The Impact of Videoconferenced Hearings on Bail Decisions, Journal of Criminal Law and Criminology. Volume 100 Issue 3 Article 8. 2010. -P.877.

8. Arkhipova E. The use of videoconferencing in the corner proceedings of Russia and foreign countries (comparative legal study). - M., 2013. P.6. 
9. Decree of the President of the Republic of Uzbekistan "On measures to radically improve the activities of internal affairs bodies in the field of crime investigation" dated April 18, 2017 No. PP-2898. Meeting of the legislation of the Republic of Uzbekistan, 2017, Article 17, Article 290.

10. Response to the Questionnaire Regarding Video Conferencing Capabilities of the Eight. Cologne, January 1999. The Lyon Group. G8 Senior Expert Group on Transnational Organized Crime. Provisional Archive: June 1995 - June 1999/ Published: November 14, 1999/ Designed and Published by the Rule of Law Foundation for free distribution within the Lyon Group, with support from the U.S. Department of State/ Washington, DC USA. - p. 5 - 8;

11. Canadian Criminal Code (R.S.C., 1985, c. C-46). [Electronic resource]: http://laws-lois.justice.gc.ca/eng/acts/ 